\title{
A CRÍTICA CULTURAL DO JOVEM GLAUBER ROCHA NO SUPLEMENTO DOMINICAL DO JORNAL DO BRASIL: IMPASSES E ESTRATÉGIAS ADOTADAS NA CHEGADA AO RIO DE JANEIRO.
}

\author{
Arlindo Rebechi Júnior ${ }^{1}$
}

\begin{abstract}
Resumo: A chegada de Glauber Rocha ao Rio de Janeiro pode ser considerada um marco para as movimentações do Cinema Novo, no início dos anos 1960. Já em 1959, Glauber inicia suas colaborações no famoso Suplemento Dominical do Jornal do Brasil. Este artigo percorre suas principais contribuições feitas no periódico carioca com o propósito de apontar as estratégias e formulações do jovem intelectual baiano para a promoção de um debate sobre as formas do cinema moderno brasileiro em curso e a relação deste com as outras formas de arte.
\end{abstract}

Palavras-chave: Glauber Rocha; Suplemento Dominical do Jornal do Brasil; Cinema Novo; sociabilidade intelectual.

\begin{abstract}
Glauber Rocha's arrival at Rio de Janeiro can be considered a milestone for the Brazilian Cinema Novo movement in the early 1960s. In 1959, Glauber starts his collaborations in the Suplemento Dominical do Jornal do Brasil. This paper examines Rocha's major contributions in this newspaper for the purpose of pointing out the strategies and formulations of the young intellectual from Bahia to promote a debate on the forms of modern Brazilian cinema and its relationship to other art forms in the 1960s.
\end{abstract}

Key-words: Glauber Rocha; Suplemento Dominical do Jornal do Brasil; Brazilian Cinema Novo; intellectual sociability

\section{O encontro com o Rio: abrem-se as portas do Jornal do Brasil}

As memórias de Paulo César Saraceni (1993) são um precioso documento da movimentação dos jovens do Cinema Novo, pois, antes de qualquer coisa, fornecem uma ambiência da amizade com o então desconhecido Glauber e o flerte deste com os locais cariocas. O jovem baiano iniciara suas viagens ao Rio de Janeiro ainda em fins do decênio de 1950, em concomitância às suas atividades de crítico nos jornais baianos e às suas primeiras realizações como cineasta, jovem cineasta.

Em 1959, ambos, Saraceni e Glauber, finalizavam seus primeiros curtas-metragens e o ponto de encontro deles passou a ser os corredores da famosa Líder Laboratórios, na rua Álvaro Ramos, no bairro de Botafogo. Saraceni conta que a primeira vez que encontrou Glauber no Rio de Janeiro, época quando ainda não tinha sequer ouvido falar do jovem

\footnotetext{
${ }^{1}$ Doutor em Letras pela USP.
} 
baiano, foi por intermédio de Miguel Borges e Carlos Pérez num encontro no famoso bar Alcazar. Na mesma ocasião, Glauber apresentou-se como cineasta baiano, pedindo-lhe o telefone para um posterior contato, o que não demorou. Já no dia seguinte, Saraceni receberia seu telefonema com o propósito de marcar o primeiro encontro daquilo que se tornaria uma efetiva amizade nos anos seguintes, uma significativa e simbólica amizade no círculo do Cinema Novo. Desse registro, é interessante notar a figura constituída por Saraceni em relação a Glauber, saldo, saliente-se, das memórias já embargadas e enformadas pela silenciosa marca roedora do tempo:

[...] disse que queria ser meu amigo, que eu era o único que tinha feito um filme, tinha dado, como ele, o salto da teoria para a prática. Gostei, fui ao encontro de Glauber, nos tornamos grandes amigos. Os dois filmes, o meu e o dele, estavam montando o negativo com o Sousa, que tinha uma moviola $16 \mathrm{~mm}$, numa vila ao lado da Líder em Botafogo. Começamos juntos a frequientar o bar em frente à Líder, que era um botequim com ótimo chope, e trocamos muitas idéias e confidências. Eu via Glauber todos os dias, e estava espantado e surpreendido. Baiano do sertão, meio Riobaldo, meio Diadorim, de Vitória da Conquista, e sabia tudo. Radical e violento na sua revolução, que era doce e brasileira. Protestante, contestava a sociedade e o regime com vigor, e bom caráter. Tinha idéias geniais. (SARACENI, 1993: 43-44).

Em meio aos prováveis lapsos de lembranças do autor de Porto das Caixas nessa sua rememoração de Glauber, o traço, sem sombra de dúvida, mais marcante é o jovem que vem de longe para iniciar sua amizade sob os laços de um projeto intelectual comum. Não é à toa que esses primeiros encontros de Glauber sempre guardam o seu lado insistente em mostrarse integrante de um mundo intelectual compartilhado: em pauta, é a onda de fazer um filme e o vigor de participar e topar quaisquer discussões teóricas em torno da nova arte. Para quem estivesse na mesma via, Glauber demonstrava apreço, pontapé inicial para uma amizade que poderia ser duradoura ou não, a depender dos desdobramentos. Talvez fosse por esse modo prático, escolhendo seu correspondente intelectual a partir de suas ações de visibilidade na capital carioca e já empreendendo o fino trato da amizade, que ele tenha encontrado uma maneira mais profícua de se estabelecer num primeiro momento naquilo que the parecia alheio, embora muito sedutor: o Rio de Janeiro. Nessa maneira de estreitar vínculos, cuja atividade de escritor contumaz de cartas o auxiliou na forma de manutenção quando estivesse longe, é que se deu o contato com o grupo de Reynaldo Jardim, que coordenava as páginas do Suplemento Dominical do Jornal do Brasil (SDJB). 
Sempre lembrado pela crítica especializada glauberiana e por seus inúmeros biógrafos, um fato anotado por Glauber em seu livro Revolução do cinema novo e também registrado por Saraceni em suas memórias parece dar uma dimensão do funcionamento dessas relações preconizadas pelo crítico baiano em terras cariocas, demonstrando como suas ligações aos grupos intelectuais locais fortaleciam-se na medida das contingências de suas ações. Volte-se a atenção ao famigerado "Manifesto bola-bola". Tudo começa com a organização por Glauber, em 1959, de uma seção carioca para a apresentação de seu primeiro filme de curtametragem Pátio e o filme, também curta, de Saraceni, Caminhos. O local agendado para o evento era a casa de Lygia Pape e lá estaria fração atuante de intelectuais do Rio de Janeiro daquele tempo, entre eles: Mário Pedrosa, Décio Vieira, Ferreira Gullar, Amílcar de Castro, Hélio Oiticica e o próprio Reynaldo Jardim. É de se supor que os filmes e as polêmicas geradas em torno deles impressionaram este último, que de imediato ofereceu o espaço do SDJB para que Glauber e seus jovens amigos de cinema do Rio pudessem escrever um manifesto. Conforme lembra Saraceni, Glauber achou por bem - talvez por pura diplomacia delegar a tarefa de redação do tal manifesto para Miguel Borges, cuja malsucedida leitura seria feita no Alcazar, como se percebe nas palavras do cineasta carioca descrevendo sua própria reação:

Havia um ar de coisa histórica. Miguel Borges começou:

- Não queremos mais cinema-literatura. Não queremos mais cinemaescultura. Não queremos mais cinema-música. Não queremos mais cinemadança. Não queremos mais cinema-teatro. Queremos cinema-cinema.

Aí, eu pulei - todos estávamos espantados com um começo de manifesto que pretendia reinaugurar o cinema brasileiro. Aquilo era ridículo.

- Vamos ouvir o fim do Manifesto - gritavam.

- Não quero ouvir mais nada - eu disse. - Isto é manifesto dos anos 20, do cinema mudo. Pretensioso, nem Eisenstein assinaria. Ridículo. Parece o filho pedindo para o pai: Quero uma bola. Não uma bola de futebol, não uma bola de basquetebol, não uma bola de vôlei, não uma bola de pólo aquático, não uma bola de tênis, não uma bola de bilhar, não uma bola de pingue-pongue. Quero uma bola-bola! (SARACENI, 1993: 47).

É o caso de partilhar a frase que Glauber redigiu sobre a questão e sobre o momento daqueles jovens, em seu texto agrupado em Revolução do cinema novo: "tudo era confuso" (Rocha, 2004: 50). Uma confusão que poderia ser traduzida como o despreparo do grupo, cujas ideias não formavam escopo suficiente maduro para que, como grupo de realizadores e artistas novatos, pudesse exercer um projeto intelectual coeso que refletisse em manifesto afinado político e esteticamente dentro daquelas circunstâncias de momento. É curioso notar 
que a frustração de Glauber em torno do malogrado manifesto não significou um impacto negativo em seus planos. Significava para ele que as portas do Jornal do Brasil estavam abertas para seus textos; abertas por conta, talvez, de sua estratégia em fazer circular nos meios cariocas, principalmente entre neoconcretos, seu primeiro filme experimental: Pátio.

\section{O jovem intelectual de cinema dá as caras no Rio de Janeiro}

Em 1959, Reynaldo Jardim, um dos editores do SDJB e um dos signatários do "Manifesto Neoconcreto", escreveu um texto que pode ser considerado o alinhamento de uma posição de grupo (do seu grupo ligado ao Suplemento) para o teatro e sua forma contemporânea de então. Entre as premissas levantadas pelo texto, dizia que o teatro, apesar de cobertura ampla dos principais jornais e críticos, ainda não alcançara um "plano verdadeiro de arte". Poesia, pintura e escultura, apenas estas manifestações, tinham conquistado o privilégio de um lugar no tal panteão. Ao lado do teatro, excluídos ainda estavam o cinema e a prosa literária.

As afirmações sugerem duas ordens de problemas com as quais o grupo teria que lidar: era preciso deixar à vista nas páginas do SDJB o exemplo mais apurado e procedimento técnico que melhor se ajustasse às manifestações de poesia, pintura e escultura - modelares para o campo artístico e literário brasileiro. Somado a isso, era preciso elaborar outro tipo de estratégia para as demais artes, abrindo o SDJB para artigos que pudessem, ao mesmo tempo, combater as manifestações de teatro, cinema e prosa literária em suas formas consideradas mais dependentes e construir um discurso em defesa de novos artistas e intelectuais que estivessem em concordância com tais procedimentos e via política de atuação.

Volte-se para o caso do teatro elaborado por Reynaldo Jardim. Segundo este ponto de vista, o teatro condicionara-se à paternidade literária de sua origem. Nessas circunstâncias, a solução seria pensar um teatro fruto de uma libertação da literatura, que não tivesse o propósito de uma leitura, mas apenas, numa expressão que seria bastante repercutida, o teatro por ele mesmo. Formulava-se, assim, o editor do SDJB:

Deve existir um puro conflito teatral que resulte num teatro mesmo. Qual é essa pura ação teatral é o que cabe descobrir para fazer com que essa arte torne a ter significação. Significação como arte. Este é um tema que merece ser debatido. E este bilhete é para pedir aos interessados numa renovação teatral que sobre ele se manifestem. (JARDIM, 24 out. 1959: 1). 
Tais palavras tornam-se aqui mais importantes, porque demarcam, em certa medida, a escrita política a que o grupo neoconcreto se apoiava e sob ela atuava, encontrando nas páginas do SDJB (sempre nelas!) o lugar mais propício para sua divulgação ampla e irrestrita.

Os textos de Glauber publicados no SDJB demonstram que o crítico baiano, sem ter assumido uma postura explícita de aderência aos neoconcretos, seguia a mesma guia e, portanto, compartilhava naquela situação de colaborador os anseios políticos desse grupo. Seus artigos, principalmente aqueles publicados entre 1959 e 1960, cujo tema com maior recorrência foi, sem dúvida, o cinema brasileiro, seguia a mesma cartilha de ação oferecida por Reynaldo. No caso de Glauber, como divulgador de cinema, as ideias poderiam ser convertidas da seguinte forma: era preciso expor o cinema como arte que pudesse buscar sua ação cinematográfica própria e libertária, com uma ação prática nela mesma, desligando-se de sua também paternidade literária e ganhando, a partir deste ponto, em autonomia e autoridade perante as demais artes e campos artísticos já em maioridade. Para tanto, o pensamento cinematográfico do jovem crítico baiano no SDJB, também delineado pelo aspecto combativo ao caráter industrial importado, registra a necessidade de impulsionar o cinema como a arte dos mais jovens.

Em outras palavras, tais artigos de Glauber reiteram e, em alguma medida, comprometem-se com o curso político das ideias daqueles intelectuais. Parece um tanto claro nesta situação, e talvez nem precisasse aqui registrar, que a todas essas ideias o crítico baiano foi acrescentando outras por força das repercussões e dos contatos de suas palavras com a dos outros jovens que, entre outras coisas, viam-se desejosos de construir e assumir o protagonismo no cinema brasileiro independente, este aqui entendido como a recusa de um modelo industrial que fosse mantido pelo financiamento de grandes corporações e por sedentos produtores comerciais. Cabe um desses exemplos.

Em 24 de outubro de 1959, mesmo dia de publicação do polêmico bilhete de Reynaldo Jardim, Glauber publicou o artigo "Orfeu metafísica de favela" com comentários em torno do filme Orfeu negro, do diretor francês Marcel Camus. O descrédito de Glauber para com Camus não é à toa. Não se trata tão-somente da teimosia de um jovem em formação nos anos 1950-60 em relação a um estrangeiro europeu representante de um cinema de formas mais homogeneizadas e que estivera por estes lados para construir uma narrativa toda ela filmada nas praças cariocas. Convém, em relação a este caso, notar o que está contemplado em sua estratégia de defesa de um novo caminho para o nosso cinema.

Glauber engrossou o coro dos críticos que, em Orfeu negro, notavam apenas a exploração da miséria por uma solução em nome do exotismo. É o negro, a favela no morro, o 
samba que ofereciam a nova roupagem ao universo mítico de Orfeu. Ora em crítica mais velada, ora em crítica não tão velada assim, Glauber se volta contra a arte sedimentada pelo abuso do lirismo e, para tanto, assume os riscos de tomar como exemplo a relação de Vinicius de Moraes e o filme. Baseado numa adaptação de Orfeu de Conceição, de autoria deste poeta brasileiro, o filme de Camus tem os seus diálogos traduzidos para a equipe brasileira pelo próprio Vinicius, vindo daí um dos ataques mais insinuantes:

Vinicius de Moraes já é em si um poeta literário. Literário no mau sentido de coisa derramada, romantizante, sensivelzinha com pombos, plumas e passarinhos voando por caminhos de flores. Tudo isso há em 'Orfeu'. Sabemos que não foi Vinicius quem escreveu os diálogos. Mas, traduziu. E se seu espírito fosse contrário ao ambiente de lirismo frouxo, ele cortava e metia tudo num português decente. Mas o fato é que ninguém quis perder a oportunidade, ninguém quis fazer o sacrifício que gera, como em 'Il Tetto', de De Sica \& Zavattini, a peça prima. (ROCHA, 24 out. 1959: 1).

Se partirmos do pressuposto que Glauber, dada sua relação construída com o grupo do SDJB, esteja em estreita linha política amparada pelo grupo de neoconcretos naquele momento, não é forçoso concluir que a crítica ao filme de Camus pela via de um de seus colaboradores, que fora o próprio "poetinha", alcança duas funções com uma só ação. A crítica é não só voltada ao excesso de lirismo de Vinicius como é também o ataque ao conservadorismo que envolvia todas as escolhas de Camus, um filme, aliás, rico em excessos líricos. Duas formas, de se fazer cinema e literatura, que conflitavam com a forma política que o jovem crítico se guiava naquele momento nas páginas do veículo carioca. A crítica glauberiana, como modo de registrar um aspecto negativo da narrativa, salientava o diálogo entre esta forma do fazer literário e a forma do fazer fílmico presente no tecido discursivo de Orfeu negro, discordando do que supunha ser uma amarra literária a que o filme trazia consigo. A metafísica de favela, a que o título já arremete, está enfeixada justamente neste "lirismo frouxo", categoria, esta, determinada na reflexão de Glauber. A gramática cinematográfica de Orfeu, assim, pouco ou nada diz de substancial para o cinema no mundo das artes. Apenas reproduz, sem implicações, a marca homogeneizada de uma forma global do narrativo-dramático, de base americana dos grandes estúdios. A favela retida dentro de um mundo enquadrado pelos planos americanos dos personagens revela que o seu autor nada mais é que o retrato da crença de um mundo sem conflitos, envolvido com os mascaramentos dos embates ideológicos. Sua análise parece bastante esclarecedora de seu ponto de vista: 
Que era que Camus pensava que favela carioca fosse? Uma obra de arte vale pelo que vale, pela sua expressão e não pela sua intenção. O filme vale pela sua feitura, pela sua linguagem fílmica, pelo seu mundo que o fílmico cria ou recria. Seja qual for o mundo: de esquerda ou de direita. Mas olhemos de outro lado: se o artista já vem previamente munido de uma intenção, se ele quer dizer alguma coisa - e principalmente em cinema que é 'culturalmente' um instrumento social -, de ação social - como bem justifica Albert Camus (digo o outro Camus), no prefácio de 'I Want to Live' - ele tem que ser positivo, melhor, progressista, voz de denúncia. Não há tempo, em lugar nenhum, para lirismo. Se o homem-artista é francês e lá existe o puro Desespero, então fique por lá. A favela é a favela. É uma chaga social, uma chaga mesmo. Não nos interessa falar em defesa da favela porque agora mesmo ela vai ser pintada pelo Turismo para ser mais linda. Lá na favela há um drama. Não é de metafísica: é de fome. Não se tem o direito, diante de uma pessoa que passa fome, de se fazer a mínima literatura com a fome. (ROCHA, 24 out. 1959: 1).

O que extrair dessa concepção de Glauber? Há nela, mesmo que em gênese e, portanto, ainda em transformação, uma forma de se pensar o filme nacional. O exemplo que vem de fora e que apenas incentive uma forma de reprodução de prática cinematográfica não é bem quisto por ele. Tanto o exemplo de fora como o filme almejado por nossos cineastas, ambos só teriam alguma validade caso houvesse a exploração da forma fílmica em todas as suas particulares potencialidades, longe da mesmice da montagem cronológica de ligação, do ritmo pouco ou nada conflitivo e do enquadramento que não problematiza aquilo que se está enquadrando. $\mathrm{O}$ enquadramento da favela, assim como do pescador, do homem do sertão, da paisagem árida, só faz algum sentido, dentro dessa linha, caso existam implicações que mobilizassem o espectador e o retirassem de sua zona de conforto. Há, neste caso, uma tendência para um tipo de cinema menos contemplativo. Tratar o cinema por ele mesmo como uma arte possível será uma das suas tônicas dos seus artigos no SDJB.

Chamo, neste momento, a atenção para três outros artigos. Agrupei-os pela ligação que eles possuem. Constituem um laço ensaístico comum do que Glauber pensava sobre o cinema entre o ano de 1959 e 1960 . Começo pelo mais antigo deles.

Em 5 de abril de 1959, foi publicado o artigo "Sete pontos: cinema brasileiro". Com ele o crítico baiano trazia a lume uma série de ideias que davam continuidade às suas afirmações em defesa de uma base para a formação de um cinema brasileiro a partir dos seus elementos intrínsecos. Um cinema brasileiro por ele mesmo. Questão preliminar, não por isso menos importante, pensava ele que era preciso chamar a atenção de sua própria geração para que novos jovens pudessem se formar num renovado clima de investigação em torno da nova arte, em que vale a "atitude em aplicar a câmara como instrumento de pesquisa do objeto em categoria de absoluto despojamento de artes plásticas ou literatura" (Rocha, 5 abr. 1959: 5). 
Tal como o teatro defendido por Reynaldo Jardim, o cinema dessa nova geração, na fala agora de um de seus porta-vozes do $S D J B$, nasceria de um novo tipo de profissionalização conduzida apenas pelo "princípio de cinema - cinema mesmo". Antes, porém, seria preciso ligar os jovens a esta nova visão, uma "visão filmológica", formulada do entendimento do saber fílmico com base nos conhecimentos "da estrutura e da essência da montagem" e do saber cinematográfico, este mais preocupado com o complexo cultural a que está sujeito. Como modo de construir discursivamente a nova história do cinema brasileiro, Glauber toma para si uma responsabilidade. Quer apresentar, não se distanciando da linha do $S D J B$ e nem tampouco do que já começava a acertar com o grupo de jovens cineastas do Rio, um dossiê, o mais completo possível, dos problemas e das soluções do mundo do cinema, tal como se apresentasse um novo modelo de prática artística para o caso brasileiro. Um novo modelo desejoso de fundar.

Se a nova geração, como afirma, ainda não está preparada para assumir a responsabilidade criadora do nosso cinema, havia sido pelo motivo de não ter tido uma geração antecessora na qual esta pudesse se espelhar. Isso, por outro lado, não incompatibilizaria a formação deste novo cinema. Dependeria de outros fatores, que são assim colocados por Glauber:

\footnotetext{
Essa disciplina filmológica é, pois, o que equilibraria novas gerações. Os rapazes em geral estão pretendendo mais do que podem técnica e economicamente. Mesmo como artesãos de montagem. Já se confiam sem o planejamento e a dinâmica físico-intelectual que são constantes indispensáveis no cineasta. Sofrem, por fim, do mal da 'não vivência', vivência que, mais do que o poeta, o cineasta necessita. Sendo cineasta, e não literato ou mistificador desse meio de expressão, ele é forçado a recolher no real seu visual. E para compreender esse real, é necessário vivenciá-lo. (ROCHA, 5 abr. 1959: 5).
}

Não havia dentro do cinema brasileiro cineasta que já tivesse, de fato, vivido essa tal "visão filmológica". Dentro desta lógica tecida por Glauber, mesmo os cineastas considerados mais "sérios" - Nelson Pereira dos Santos, Roberto Santos, Rubem Biáfora, Galileu Garcia, Walter Hugo Khoury e irmãos Santos Pereira - ainda não constituíam massa crítica capaz de fazer o deslocamento necessário em direção à mudança paradigmática prevista por ele para privilegiar o cinema como a nova expressão artística moderna por excelência. Na estratégia de Glauber transborda-se seu desejo (e tática) da própria participação nesta nova construção que se vislumbrava. Dito de outro modo, projetava-se uma necessidade por ele formulada e que 
seria a base para as futuras inserções sociais desta nova classe a partir de um movimento intelectual, por assim dizer, agregador:

Dada a nossa pobreza, qualquer idéia para uma organização estética e industrial seria justa e plenamente aceitável. O que não se pode aceitar é desunião fundamental que existe entre cada homem de cinema 'sério' no Brasil. Há carência de 'pensadores'. A crítica é apenas racista de filmes, ainda mais deficiente do que a literária. Os mineiros falam em 'revisão do método crítico', mas até hoje não se sabe bem qual seja tal método e qual influência teria a revisão no pensar cinema no Brasil. As atenções teóricas voltam-se para fora, e ainda assim não teorizam mas apreendem teorias que jamais são aplicadas. [...] A verdade é que a preocupação de fazer cinema se prende a uma necessidade mais individual, embora entrevistas anunciem preocupações coletivas. [...] Movimento, pois, entre nós, seria um pensador que surgisse unindo todos os profissionais em torno de uma idéia, jamais uma academia mas, pelo menos, uma tentativa de salvar a classe mais jovem profissionalizada, essa classe que já é decepção. (ROCHA, 5 abr. 1959: 5).

Estabelecido o contato inicial, deixando o recado para os mais jovens, ainda não profissionalizados, e o alerta para os cineastas "sérios" já com inserção neste novo mercado de bens culturais, embora estes considerados uma "classe de decepção", o passo seguinte do crítico baiano foi desdobrar tais colocações e mostrar quais os novos caminhos que poderiam ser considerados profícuos para o novo projeto de estabelecimento do espaço para a nova arte.

O artigo "Cinema: operação Nordeste", publicado meses depois, em 12 de dezembro de 1959, pode ser considerado uma destas tentativas. Uma de suas apostas foi considerar que a força deste novo cinema surgiria da dimensão da expressão fílmica submetida à temática da realidade nacional, extraindo então sua matéria vertente mais rica. Dali surgiria a nova expressão do cinema nacional. Não parece à toa que seu texto chame a atenção para o deslocamento de duas equipes para o Nordeste para as filmagens dos trabalhos de dois cineastas, estes considerados por ele como inseridos no grupo dos "sérios": Nelson Pereira dos Santos e Trigueirinho Neto. Para Glauber, tratava-se de um início, o começo de uma ruptura: "dois cineastas da geração atuante do chamado filme sério abandonam a Metrópole sulina (Rio e São Paulo)” (Rocha, 12 dez. 1959: 5).

Sem desprezar que esta iniciativa de Glauber já trazia em si as contribuições das discussões que ele iniciara com o grupo de jovens cineastas do Rio, repercutindo nas suas palavras um sentimento de ansiedade do próprio grupo na busca de uma força motriz intelectual mais robusta que pudesse distingui-los como intelectuais de inserção na nossa cultura, a visão tratada pelo crítico buscava um marco histórico de formação do nosso cinema. Num ponto de vista que possa se ancorar tanto em uma perspectiva que demarque 
acontecimentos e conjunturas estabelecidos em momento histórico anterior como em uma perspectiva que registre mudanças estruturais significativas ao ponto de orientar um novo modelo. Trata-se, sem dúvida, da convenção de um novo marco histórico, cujos pontos de referência são aplicados à análise do passado, mesmo que este possa significar esvaziamento de uma tradição, e ao ponto de mudança no presente, a pedra de toque para uma nova história que se formulava.

Glauber é específico em sua formulação. Um novo período se inauguraria com a saída do filme da cidade, sua saída "do drama de apartamento, do melodrama de boate, do neorealismo de subúrbio" (Rocha, 12 dez. 1959: 5). Tal equação é formulada sob duas necessidades de defesa: o cinema como arte autônoma e representativa de um mundo desenvolvimentista em fomento e o Brasil como ideia e ressonância de um debate bastante presente desde os tempos do nosso modernismo nos primeiros decênios daquele século: o que somos afinal? Tratava-se da pergunta central e, em consequência, ditaria o tom das novas formulações do nosso cinema na década que se iniciava. A geração de jovens cineastas e ele como um dos principais porta-vozes no $S D J B$ não demorariam para levantar a bandeira de uma arte construída para o registro em forma de denúncia de uma realidade marcada pelas nossas assimetrias sociais, tornando-se, esta, a base de argumentação que se apresentaria em artigos de jornais, em parte significativa dos filmes em gestação e nos textos-manifestos. Convertidos ao sentimento geral que contaminava uma esquerda brasileira no pré-1964, havia a crença em todos eles de que esta mesma realidade ofereceria a melhor maneira de explorar com originalidade a linguagem para um legítimo cinema brasileiro ${ }^{2}$. As palavras de Glauber beiram a constatação das coisas presentes e sugere um prognóstico, diria otimista, de tais transformações:

Pelo menos as novas gerações, um pequeno grupo mais jovem do que o atuante, compreendem que o filme brasileiro não pode começar a viver na

\footnotetext{
${ }^{2}$ É bastante ilustrativo da atmosfera desse momento o célebre artigo "Cultura e política, 1964-1969”, publicado originalmente por Roberto Schwarz, na revista francesa Les Temps Modernes, em 1970. Deste referido texto do ensaísta interessa o trecho em que ele busca esmiuçar as origens do colapso posterior à implantação da ditadura militar. Sua análise, assim, volta-se para o clima de antes de 1964, momento em que "o socialismo que se difundia no Brasil era forte em antiimperialismo e fraco na propaganda e organização da luta de classes" (Schwarz, 2008: 73). Interessa saber que para o crítico, por inúmeras razões, entre elas a estratégia conciliadora do Partido Comunista, havia se construído no Brasil "uma espécie desdentada e parlamentar de marxismo patriótico, um complexo combativo e de conciliação de classes, facilmente combinável com o populismo nacionalista então dominante" (Schwarz, 2008: 73). Já numa chave de leitura um pouco distinta, não na mesma "atualidade de então" do crítico de Ao vencedor as batatas, Ismail Xavier, ensaísta não menos importante, consegue penetrar tais transformações do pré-1964 e, sobretudo, do pós-1968 pela via do cinema. Seu livro Alegorias do subdesenvolvimento, publicado em 1993, analisa as transformações que ocorreram dentro da representação alegórica no cinema brasileiro dos anos 1960. Para isso, o crítico volta-se para o entendimento do processo que marcou a passagem do Cinema Novo para o Cinema Marginal, na conjuntura do pós-1968.
} 
metrópole e por isso deve penetrar, buscar não só o testemunho social como a matéria para trabalhar uma expressão nascida dela mesma, sem fazer manobras com a linguagem dos outros. Depois há o campo para se começar a armar a indústria: na jungle há matéria exportável, sem concorrência no mercado estrangeiro, material para a exploração a longo prazo. Não se pode exigir para o filme nacional de hoje a consumação e a urgente crise intelectual de todos os cinemas tradicionais. (ROCHA, 12 dez. 1959: 5).

Completam-se aos dois artigos antes expostos em relação ao emblemático período 1959-1960, seu fundamental texto “Bossa Nova' no cinema brasileiro”, cuja publicação é datada de 12 de março de 1960. Supondo ele a impossibilidade de se escrever sobre uma relevante geração ou um movimento com fortes implicações na história do nosso cinema, Glauber registra, todavia, que haveria uma "bossa nova" conduzida por alguns jovens cineastas (os tais cineastas "sérios") que buscavam construir um cinema consciente do processo emancipatório em realização. Era o passo, portanto, para se criar uma forma de identidade do nosso cinema sem precedentes:

as condições de produção são mínimas, os filmes realizados são de baixo orçamento e a pobreza técnica não impede que eles deixem de dizer alguma coisa, mesmo que esta coisa esteja respondendo ainda a realidades particulares, desprovidas de uma ligação que já resistisse ao selo de movimento. (ROCHA, 12 mar. 1960: 5).

Saliente-se, porém, que o seu texto não objetiva tão-somente o elogio à missão destes novos cineastas da referida "Bossa Nova". Ao menos, isto não é o principal a ser tratado. Sua razão fundamental está baseada no registro da importância do encontro entre estes cineastas "sérios", a tal geração bossa nova, e os cineastas de uma nova geração, na qual ele se inclui e que denominou ser a "bossa novíssima" do nosso cinema. A oportunidade de Glauber é ímpar e ele a encara como a mais apropriada para a apresentação desses novos moços de cinema, que sua visão trata logo de fazê-los surgir "quebrando a eterna monotonia de gerações literárias e plásticas" (Rocha, 12 mar. 1960: 5), reiterando, mais uma vez, a crença de que estaria se processando o nosso novo cinema, formulado por uma colaboração de várias partes e linhagens, cuja produção independente (portanto, menos industrial) viabilizaria um tipo de arte em que não seria necessário pagar o preço por uma ideia.

Por este e outros aspectos, a defesa do cinema nacional empreitada por Glauber posicionava-se como a reação de sua emergente geração artística contra um suposto servilismo estrangeiro. Duas questões garantiriam neste planejamento de ações seu fator de sucesso: 1) era preciso que a nova geração, além de apresentar seu problema de ordem 
estética, deixasse clara sua ordem programática de movimento em processamento, sob o impulso político de se organizarem para o enfrentamento dos intelectuais já estabelecidos no circuito cultural; 2) era preciso que a matriz de cinema brasileiro nascesse sem a dependência do cânone dominante de outro cinema moderno; se isso não fosse totalmente possível, seria necessário pelo menos salientar nos textos a recusa aos padrões e influxos externos. Assim, não é de se estranhar que naquele momento Glauber saísse ao ataque a todos os cinemas que pudessem fazer tal frente, embora, faça a ressalva, o futuro diria que muito daquele nosso cinema novo em gestação tenha vindo, entre outras coisas, daquele intercâmbio com franceses e italianos. É comum na argumentação glauberiana frases do tipo: “quem não acreditar em nossas palavras, está desafiado para assistir a A Garganta do Diabo, Bahia de Todos os Santos e Vidas Secas, e depois responder se há ou não há, no Brasil, material muito melhor do que nouvelle-vague" (Rocha, 12 mar. 1960: 5).

No caso de Glauber, o SDJB tornou-se o espaço privilegiado para enredar uma ideia de processamento de uma nova forma para o cinema brasileiro. Em carta endereçada por Glauber a Gustavo Dahl, Paulo César Saraceni e Joaquim Pedro de Andrade, em 13 de junho de 1961, faz-se o registro da inclusão do referido periódico carioca no projeto de divulgação programática daqueles jovens:

Precisamos trabalhar muito: e no Brasil. Nosso grupo tem de ser um verdadeiro motor. Não podemos parar, fazendo filmes, discutindo e escrevendo. O Jornal do Brasil vai acabar o Suplemento, o que vai me deixar sem armas. Mas consigo outro jornal. É importante que Gustavo escreva para o Estadão. Não pode parar. Mais tarde faremos uma revista. Vou fazer aqui na Bahia a Bienal do Cinema Brasileiro, na Bienal Nacional, que o Museu vai organizar. (ROCHA, 1997: 158159).

Se o movimento modernista literário e artístico fora operacionalizado nos anos 1920 e estivera conectado às próprias mudanças urbanas e econômicas, a operacionalização deste novo cinema cumpre, dada as diferenças de época na comparação, uma nova etapa de modernização de um campo artístico brasileiro. O cinema brasileiro moderno ${ }^{3}$ desenrolara-se

\footnotetext{
${ }^{3}$ Tomo aqui de empréstimo este termo consagrado por Ismail Xavier, a partir do seu texto "O cinema brasileiro moderno", publicado em livro homônimo de 2001. O crítico vai apontar que o nosso cinema nos anos 1960, em sua variedade de estilos, conseguira acertar "o passo do país com os movimentos de ponta de seu tempo" (Xavier, 2001: 18). A ideia de cinema moderno está intimamente ligada às renovações estéticas ocorridas na arte brasileira, desde as movimentações modernistas dos anos 1920. Significa dizer que a produção cinematográfica, conduzida, esta, por jovens críticos e intelectuais de esquerda formados em diversos cineclubes, conseguira, finalmente nos anos 1960, - embora tardiamente para a história do nosso cinema - movimentar o diálogo com outras tradições artísticas mais consolidadas, tais como a literatura brasileira.
} 
de uma nova onda desenvolvimentista, embora não só a partir disso. Era preciso também entender que a malograda indústria de cinema, em surtos sempre mal resolvidos e mal vistos pela classe intelectual de esquerda, estimulara a iniciativa daqueles jovens pela opção do cinema independente ${ }^{4}$ em reação à ideia de imperialismo cultural que aquele tipo de cinema de estúdio trazia consigo e representava.

Para refletir sobre a questão antes exposta, concentremo-nos um pouco mais em 1961. É um ano fundamental para o jovem Glauber. Época de consolidação de sua rede de relações e amizades. Ora com domicílio no Rio, ora com domicílio na Bahia, e com atuações concomitantes na imprensa de ambos os locais, Glauber formulava nos bastidores, junto com outros jovens cineastas de mesma geração - intelectuais que seriam a base do movimento do Cinema Novo -, os passos de um presente e de um futuro em torno dos projetos de filmagens e de intervenções escritas. Somado a isso, consolidara o diálogo com um dos principais intelectuais do cinema cubano, Alfredo Guevara. Com este, Glauber manteve uma constante troca de cartas por um longo período ${ }^{5}$. Guevara dava ao cineasta baiano a dimensão do que acontecia na famosa ilha, nutrindo-lhe ainda mais o imaginário com projetos que ultrapassavam, em longe, o âmbito das nossas fronteiras.

Sem a autocensura e autoavaliação tácita à estratégia imposta à escrita de um artigo de jornal, em que cada palavra dita a um heterogêneo e imaginado leitor deve ser medida (numa atitude ética, sobretudo) e vez por outra suprimida, sua correspondência desnuda outro tipo de relação com a palavra. A troca de cartas entre Glauber e alguns destes jovens intelectuais brasileiros é referência. Tais cartas dão os contornos do frisson causado por projetos em andamento, recepções motivadas por pequenas intervenções e brigas entre o grupo e opositores.

Veja-se o seguinte exemplo: em maio de 1961, estavam fora do Brasil, participando do Festival de Cinema de Santa Margherita, na Itália, os jovens Joaquim Pedro de Andrade,

\footnotetext{
${ }^{4}$ A ideia de um cinema independente se contrapõe à ideia de um cinema industrial, típico do modelo dos grandes estúdios americanos. Não só isso. O cinema independente no Brasil se liga à ideia de um cinema de perspectiva autoral. Veja-se o exemplo das leituras dos filmes de Rogério Sganzerla e Júlio Bressane feitas por Jean-Claude Bernardet, no seu livro $O$ vôo dos anjos: Bressane, Sganzerla, de 1991. São leituras que demonstram, no caso brasileiro, a fértil ligação cinema independente-cinema de autor. Na formulação de Ismail, seria um tipo de cinema que "assume uma relação mais tensa com as fórmulas muito codificadas ou apelativas" (Xavier, 2001: 62).

5 Além das cartas publicadas de Alfredo Guevara, na correspondência de Glauber, no livro Cartas ao mundo (1997), é preciso destacar a edição do diálogo epistolar entre o cineasta brasileiro e Alfredo Guevara no pouco difundido livro Um sueño compartido: Alfredo Guevara - Glauber Rocha, de 2002. Esta relação é ainda muito bem historiada por Mariana Villaça (2002), no artigo "América Nuestra: Glauber Rocha e o cinema cubano", que além de delinear a relação do cineasta brasileiro com o Instituto Cubano Del Arte e Indústria Cinematográficos (ICAIC), também analisa a repercussão da obra glauberiana entre cineastas de Cuba. Ver ainda sobre esta questão, a relevante tese de doutorado de Maurício Cardoso (2007: 18), cujo foco são os filmes de Glauber feitos no estrangeiro.
} 
Gustavo Dahl e Paulo César Saraceni, sendo este último o único premiado brasileiro, com o filme Arraial do Cabo. Cada carta recebida e enviada por Glauber dos e aos amigos é o detalhe de como as coisas funcionavam na dimensão mais íntima dos seus contatos. É o recado do que acontecia com outros latino-americanos: "De uns dois anos pra cá os argentinos fizeram pelo menos dez filmes realmente novos, sobretudo pela mise em scène" (Rocha, 1997: 154). É a notícia dos enfrentamentos: “Aqui em Santa Margherita vamos brigando com todos os canalhas e no Brasil a briga será maior. Você, Paulo César, Gustavo, Mário e eu, outros que mais tiverem força e entusiasmo, vamos arrasar com os Fernandos de Barros todos" (Rocha, 1997: 155). É o recado de amigo que configura os laços de amizade e identidade em torno de uma mesma causa: "Aguenta a parada, caro amigo - agora que a coisa começou - eu, Joaquim e Gustavo estamos unidos e estamos contigo, chegou o tempo da gente fazer o filme que queremos fazer - nós contra aqueles filhos das putas" (Rocha, 1997: 156). É a resposta de Glauber que insere a causa individual de cada um na ordem coletiva de interesses:

[...] do Brasil, Argentina, Cuba e outros latinos nascerão filmes fantásticos. eu já estou articulado com os cubanos, articulados demais. Lá eles estão montando uma indústria. Se vocês já têm ligações com os argentinos, então poderemos fazer um movimento ambicioso, sul-americano, um movimento de força, independente, capaz de derrubar a porcaria de GEICINES [Grupo Executivo da Indústria Cinematográfica] e estas lesmas cretinas do nosso velho cinema. O grito de independência já foi dado com Arraial. Que filme brasileiro tirou tanto prêmio, filme pobre e sem coberturas oficiais? Arraial pode representar o início de uma nova época no cinema nacional e vou escrever sobre isto no Jornal do Brasil. O Gustavo devia mandar a história de Santa Margherita para O Estado de S. Paulo. É importante que no Brasil se fique sabendo do que houve. (ROCHA, 1997: 157).

Em 1961, às vésperas de finalizar seu primeiro filme de longa-metragem, Barravento, talvez já pela notória repercussão de seus textos na capital carioca, talvez pela forte ligação e segurança que a amizade com os jovens intelectuais desta mesma cidade lhe garantia, Glauber soube avaliar o clima propício para a escrita de um artigo certeiro e já, de certa forma, síntese fundamental da movimentação daqueles novos e barulhentos cineastas, transparecendo, na forma que beira o manifesto, a opção por um cinema de autor. Não por menos ele o incluiria no início de seu livro Revolução do cinema novo como uma das plataformas de sua geração.

Intitulado "O processo cinema", este artigo foi publicado no dia 6 de maio de 1961. Extenso e com características que mesclam a avaliação do artefato fílmico, a experiência de vivência de jovem cineasta e de crítico e as apostas para a criação e manutenção de uma 
classe cinematográfica única no Brasil, tal texto só poderia aparecer depois de uma longa gestação de ideias praticadas e analisadas em artigos anteriores publicados nos periódicos baianos ou no próprio Jornal do Brasil. Com uma conjuntura adequada, tendo a seu favor um veículo de imprensa de boa repercussão, com demandas do momento que valorizassem o discurso a favor de uma autêntica arte brasileira, sem que isso afetasse o discurso de valorização do trabalho autônomo e independente do artista e de sua arte, o texto de Glauber guarda em si a diversidade de tais condicionantes.

Tal artigo opera, a um só tempo, duas visões: a do crítico e a do cineasta. Cada uma delas deslizando-se uma sobre a outra, sem que se note o prejuízo ou o benefício em nome de uma delas. Espécie de pique-esconde, Glauber brinca com seu leitor. Quando pensamos estar diante do crítico é o cineasta que nos aparece. Quando estamos crentes de ser a vivência do cineasta, o crítico nos avisa que sua visão é que prevalece. As duas experiências, complementares e não excludentes, alternam-se, sem que ao certo possamos identificar com precisão tal chaveamento.

Glauber cobra de todo e qualquer artista do cinema a postura da autonomia em relação às possibilidades estéticas da nova arte. Supondo que as condições das técnicas e da economia sempre medeiam o fazer fílmico, Glauber prevê que a experiência do filme traz ao artista o dilema entre aderir ao mundo industrial e ser mutilado ou não se deixar levar pelo estrelismo e permitir que suas apostas recaiam ainda sobre o desejo de ajustar suas formas de pensamento às demandas sociais prementes. Ou seja, tornar-se um cineasta pela perspectiva autoral e com responsabilidade criadora. Mas não só com o artista que Glauber é exigente. É também com o crítico desta nova arte. Homem do gosto, o risco do crítico é, segundo ele, deixar-se enganar por aquilo que parece ser, mas não é a justa medida para um bom e honesto cinema. A integridade do cinema, neste caso, sempre passará pelo olhar ético do crítico sério e sincero, cuja capacidade de avaliação, segundo o autor, deveria estar a serviço do projeto de construção do verdadeiro cinema, longe das exigências mercadológicas.

Dividido em três partes, a última de "O processo cinema" parece ser a mais relevante para o que se propõe. É nesta parte do artigo que a mobilidade das perspectivas (a do cineasta e do crítico) manifesta-se com maior frequência. Prevalece uma atitude, não só de exposição dos problemas e constatações da própria experiência, mas também de manifestação de princípios judicativos, convocando aqueles que porventura estivessem desgarrados para uma ação mais politizada em torno da formação do novo cinema brasileiro. Não é coincidência dentro dessa opção que sua análise recaia sobre as condições do cineasta independente brasileiro. Um artista de condições precárias. 
Dentre os seus argumentos, destaca-se aquele que busca desmistificar a relação entre condições materiais para o cinema e o sucesso de um filme. Ter boas condições materiais para uma produção não seria a garantia do bom cinema, e vice-versa. Na mesma medida, boas faturas comerciais do cinema não asseguravam bons filmes.

Glauber parte de um princípio, um modelo a ser seguido: seria preciso voltar à condição primeira de artesão, com as miseráveis câmeras e com os poucos metros de filme à disposição, para, só assim, buscar a "escrita misteriosa e fascinante do verdadeiro cinema que permanece esquecido" (Rocha, 6 maio 1961: 3). No seu fiel da balança, sua opção é uma inversão na relação custo de produção-qualidade estética. Ele reverte, dessa maneira, a situação de se fazer cinema, imperativa de altos investimentos de capital, e a acomoda à situação de prática artística em condição de subdesenvolvimento com baixíssimos recursos para se investir. Ao lado da busca de um tipo de cinema muito mais autônomo, construído sem o amparo de outra modalidade artística, sem que a força de uma palavra interfira para auxiliar a imagem, mas que, enfim, a imagem seja por ela mesma o grande vocábulo de escrita do cineasta moderno, convive a preocupação em agrupar uma nova forma fílmica com os problemas e os temários existentes no país. Nessa perspectiva, faz-se todo sentido suas sugestões aos amigos: “É preciso 'nacionalizar' o negócio, tornar o problema 'real' [...] Aqui no Brasil nosso cinema deve ser inicialmente um problema mais ÉTICO DO QUE ESTÉTICO. Compreendo aos poucos que nossa ambição de puristas e formalistas deve ser esquecida" (Rocha, 1997: 158). Trata-se do mesmo caso, como Glauber frisou no SDJB, em que o cinema como veículo de ideias pode ser justo, desde que atenda à denúncia de tais assimetrias sociais. Sua experiência em Barravento é então o exemplo desse tipo de acomodação:

Quando aceitei a profissão de fazer filmes e para isso fiz a penitência de noventa dias numa praia deserta, sem muito dinheiro e com uma equipe humanamente heterogênea, só admiti aquele trabalho contrário às minhas ideias originais sobre o cinema porque tive a consciência exata do país, dos problemas primários de fome e escravidão regionais, e pude decidir entre minha ambição e uma função lateral do cinema: ser veículo de ideias necessárias. Ideias que não fossem minhas frustrações e complexos pessoais, mas que fossem universais, mesmo se consideradas no plano mais simples dos valores: mostrar ao mundo que, sob a forma do exotismo e da beleza decorativa das formas místicas afro-brasileiras, habita uma raça doente, faminta, analfabeta, nostálgica e escrava. (ROCHA, 6 maio 1961: $3)$. 
Está manifesta em tal postura o mesmo horizonte de interpretações de um dos seus grandes mestres da crítica cinematográfica. Refiro-me ao também abordado artigo "Uma situação colonial?", de Paulo Emílio ${ }^{6}$. Quando Glauber compartilha com seu leitor a humilde pergunta "não poderíamos nós, pobres cineastas brasileiros, expurgar os pecados de nossas ambições?”, por trás dela está a cisão compartilhada por tantos outros de sua geração. Uma cisão que, embora defendendo a posição do cineasta como poeta, organizador de um cinema puro artisticamente, encontra no cinema um válido "instrumento de idéias do universo" (Rocha, 6 maio 1961: 3). Talvez ainda esteja aí, neste campo de preocupações, a explicação mais adequada para se voltarem, neste primeiro momento, para a construção de um novo cinema a partir de outras paragens que não as cidades: investiram-se da coragem para olhar o asfalto das metrópoles e neles terem avistado o pseudodesenvolvimento, notando que a imagem formada pelo olhar estrangeiro, de índios de gravata e paletó, dizia muito de nossas próprias contradições. Uma das opções reflexivas do movimento gravitaria por aí.

\footnotetext{
${ }^{6}$ A complexa relação de Paulo Emílio com Glauber foi esmiuçada na tese de doutoramento de Pedro Plaza Pinto (2008: 83-106).
} 


\section{Referências Bibliográficas}

BERNARDET, Jean-Claude. $O$ vôo dos anjos: Bressane, Sganzerla. São Paulo: Brasiliense, 1991.

CARDOSO, Maurício. O cinema tricontinental de Glauber Rocha: política, estética e revolução (1969-1974). 285 f. Tese (Doutorado em História Social) - Faculdade de Filosofia, Letras e Ciências Humanas da Universidade de São Paulo, São Paulo, 2007.

GUEVARA, Alfredo (Org.). Um sueño compartido: Alfredo Guevara - Glauber Rocha. Madrid (Espanha): Iberoautor, 2002.

JARDIM, Reynaldo. "bilhete do editor. teatro mesmo". Suplemento Dominical do Jornal do Brasil (SDJB), Rio de Janeiro (RJ), 24 out. 1959, p. 1.

PINTO, Pedro Plaza. Paulo Emilio e a emergência do Cinema Novo. Débito, prudência e desajuste no diálogo com Glauber Rocha e David Neves. Tese (Doutorado em Ciências da Comunicação) - Escola de Comunicações e Artes da Universidade de São Paulo, São Paulo, 2008.

ROCHA, Glauber. “'Bossa Nova' no cinema brasileiro”. Suplemento Dominical do Jornal do Brasil (SDJB), Rio de Janeiro (RJ), 12 mar. 1960, p. 5.

"Cinema: operação Nordeste". Suplemento Dominical do Jornal do Brasil (SDJB), Rio de Janeiro (RJ), 12 dez. 1959, p. 5.

“O processo cinema”. Suplemento Dominical do Jornal do Brasil (SDJB), Rio de Janeiro (RJ), 6 maio 1961, p. 3.

"Orfeu metafísica de favela". Suplemento Dominical do Jornal do Brasil (SDJB), Rio de Janeiro (RJ), 24 out. 1959, p. 1.

"Sete pontos: cinema brasileiro". Suplemento Dominical do Jornal do Brasil (SDJB), Rio de Janeiro (RJ), 5 abr. 1959, p. 5.

Cartas ao mundo. Org. Ivana Bentes. São Paulo: Companhia das Letras, 1997.

Revolução do Cinema Novo. São Paulo: Cosac Naify, 2004.

SARACENI, Paulo César. Por dentro do cinema: minha viagem. Rio de Janeiro: Nova Fronteira, 1993.

SCHWARZ, Roberto. O pai de família e outros estudos. São Paulo: Companhia das Letras, 2008.

VILLAÇA, Mariana Martins. América Nuestra: Glauber Rocha e o cinema cubano. Rev. Bras. Hist., v. 22, n. 44, p. 489-510, 2002.

XAVIER, Ismail. O cinema brasileiro moderno. São Paulo: Paz e Terra, 2001. 